\title{
Research Article \\ Incidence of Orthostatic Hypotension in Schizophrenic Patients Using Antipsychotics at Sambang Lihum Mental Health Hospital, South Kalimantan
}

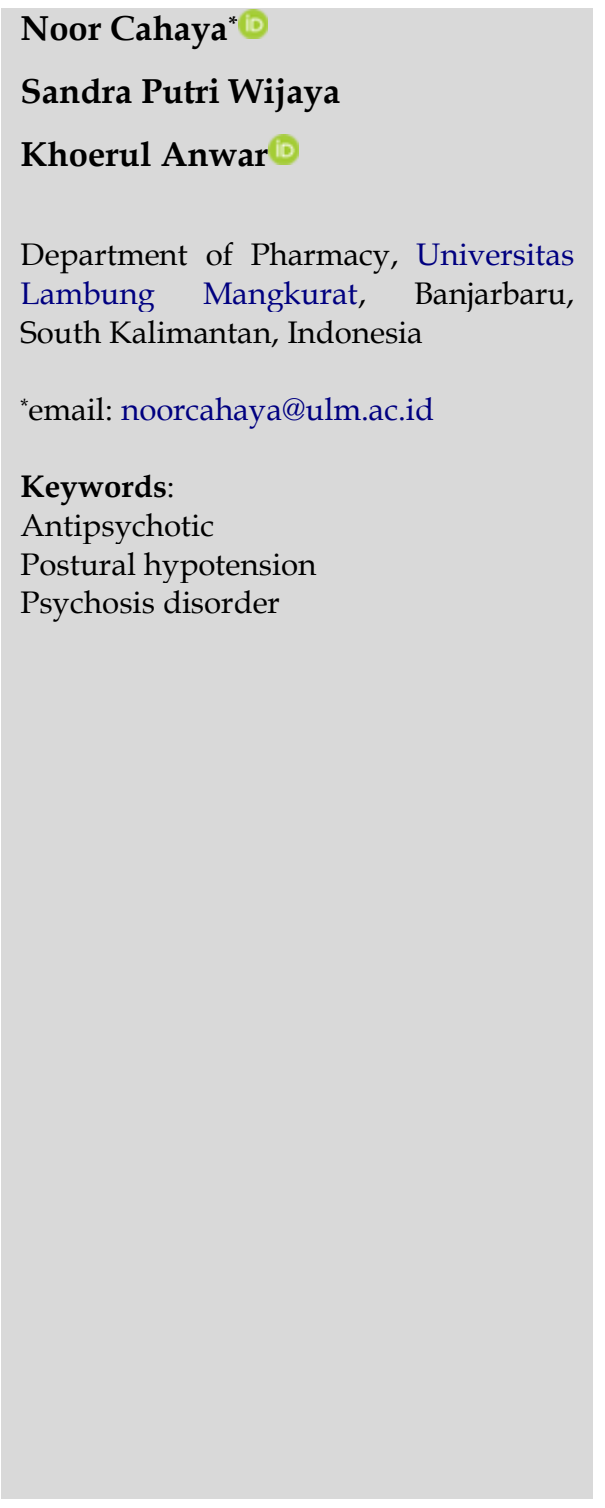

\begin{abstract}
Schizophrenia is a psychiatric disorder that requires antipsychotics therapy. Antipsychotics cause many side effects, including orthostatic hypotension. The study aimed to describe the incidence of orthostatic hypotensive side effects experiences by schizophrenia patients at the Sambang Lihum Mental Health Hospital, South Kalimantan. This research was observational description research with data sampling by medical records. This research was conducted to 300 medical records of patient's period January-December 2018 which received antipsychotics medication and data analyzed by univariate analysis. The results showed the number of patients who experienced orthostatic hypotension was 98 patients $(32.67 \%)$ and no experienced were 202 patients $(67.33 \%)$. Incidence of orthostatic hypotension in haloperidol 54.35\% ( $\mathrm{N}=46)$; trifluoperazine $100 \%(\mathrm{~N}=1)$; clozapine $84.62 \%(\mathrm{~N}=13)$; olanzapine $100 \%(\mathrm{~N}=1)$; haloperidol-chlorpromazine $27.27 \%$ ( $\mathrm{N}=11$ ); haloperidol-haloperidol $42.86 \%$ ( $\mathrm{N}=7$ ); clozapinerisperidone $16.67 \% \quad(\mathrm{~N}=6)$; haloperidol-clozapine $15.05 \% \quad(\mathrm{~N}=93)$; haloperidol-olanzapine $50 \%(\mathrm{~N}=2)$; haloperidol-risperidone $31.82 \%$ $(\mathrm{N}=22)$; trifluoperazine-olanzapine $100 \% \quad(\mathrm{~N}=1)$; trifluoperazineclozapine $22.22 \%(\mathrm{~N}=9$ ); trifluoperazine-risperidone $5.56 \%$ ( $\mathrm{N}=18$ ); chlorpromazine-haloperidol-haloperidol $\quad 33.3 \% \quad(\mathrm{~N}=3)$; chlorpromazine-haloperidol-trifluoperazine $100 \%(\mathrm{~N}=3)$; haloperidoltrifluoperazine-chlorpromazine $\quad 100 \% \quad(\mathrm{~N}=1)$; chlorpromazinehaloperidol-clozapine $42.86 \%$ ( $\mathrm{N}=7$ ); chlorpromazine-trifluoperazineclozapine $100 \% \quad(\mathrm{~N}=1)$; chlorpromazine-trifluoperazine-olanzapine $100 \%(\mathrm{~N}=1)$; chlorpromazine-trifluoperazine-risperidone $50 \%(\mathrm{~N}=2)$; trifluoperazine-haloperidol-risperidone $100 \% \quad(\mathrm{~N}=4)$; haloperidoltrifluoperazine-risperidone $100 \%(\mathrm{~N}=1)$; trifluoperazine-haloperidolclozapine $40 \%(\mathrm{~N}=5)$; haloperidol-haloperidol-clozapine $80 \%(\mathrm{~N}=5)$; clozapine-risperidone-trifluoperazine $100 \% \quad(\mathrm{~N}=4)$; risperidoneclozapine-haloperidol 20\% ( $\mathrm{N}=10)$. The conclusion from this study was the percentage of orthostatic hypotension on schizophrenia patients at the Sambang Lihum Mental Health Hospital was 32.67\% $(\mathrm{N}=98)$.
\end{abstract}

Received: December 30th, 2020

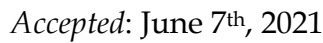

Published: August 30th, 2021

\section{INTRODUCTION}

Schizophrenia is a psychiatric disorder characterized by an impaired judgment of reality, such as delusions and hallucinations ${ }^{1}$. Approximately 20 million people worldwide have schizophrenia². Riset Kesehatan Dasar
(RISKESDAS, Basic Health Research) Data from Ministry of Health Republic of Indonesia ${ }^{3}$ in 2018 showed the prevalence of schizophrenia/psychosis in Indonesia is 6.7 per 1000 households. In Indonesia, the prevalence increased from $1.7 \%$ in 2003 to $7 \%$ in 2013. 
Schizophrenia is a mental illness characterized by several symptoms, such as positive, negative, and cognitive symptoms. To establish a diagnosis of schizophrenia in a patient, several criteria are needed, such as two or more positive, disorganized speech or behavior, or negative symptoms that have occurred for at least six months, with at least one of them being positive symptoms or irregular speech ${ }^{4}$. The pathomechanism of schizophrenia is not fully understood, so that treatment with current antipsychotics still has different effects in each case of schizophrenic patients 5 .

Antipsychotic is the primary therapy for schizophrenia. Schizophrenia requires antipsychotic therapy for a long time to cause side effects in treatment therapy ${ }^{6}$. One of the side effects of antipsychotics is orthostatic hypotension? Orthostatic hypotension is characterized by a decrease in systolic blood pressure of at least $20 \mathrm{mmHg}$ or a decrease in diastolic blood pressure of at least $10 \mathrm{mmHg}$ from normal values for three minutes in a standing position8.

Antipsychotics affect cholinergic, a-adrenergic, histaminergic, and serotonergic receptors 9 . Therefore, the antipsychotic potential to cause side effects such as orthostatic hypotension, especially antipsychotics that act as a-blockers. Neurogenic and non-neurogenic factors can cause orthostatic hypotension. Drugs, especially antipsychotics, are the most common cause of nonneurogenic orthostatic hypotension ${ }^{10}$. Antipsychotics that can cause orthostatic hypotension are considered antipsychotics that act on a-1 postsynaptic receptors like typical antipsychotics ${ }^{11}$; however, supporting data is still very limited.

Sambang Lihum Mental Health Hospital is a regional hospital in South Kalimantan, Indonesia, that provides psychiatric and non-psychiatric services. Based on data, schizophrenia is the first rank of the top 10 most diseases inSambang Lihum Mental Health. A previous study was conducted at the Sambang Lihum Mental Health stated that the side effect of orthostatic hypotension was the second highest after extrapyramidal syndrome ${ }^{12}$. Therefore, this study was conducted to assess the incidence of orthostatic hypotension in the use of antipsychotics. The study aimed to describe the incidence of orthostatic hypotension in schizophrenia patients given antipsychotic therapy at the Psychiatric Hospital of Sambang Lihum, South Kalimantan.

\section{MATERIALS AND METHODS}

\section{Materials}

The research instrument used the medical records of patients with schizophrenia from Sambang Lihum Mental Health Hospital. The data were collected using the data collection sheet.

\section{Methods}

The research was conducted in Sambang Lihum Mental Health Hospital, South Kalimantan, Indonesia. The research was approved by the Faculty of Medicine's ethics and law committee, Universitas Lambung Mangkurat, Indonesia, with No. 212/KEPK-FK UNLAM/EC/VI/2019. The study belongs to observational research with a retrospective approach. The population included patients with schizophrenia. Inclusion criteria were inpatients diagnosed with schizophrenia in Sambang Lihum Mental Health Hospital and had a complete medical record (patient's characteristic, antipsychotic therapy history). The exclusion criteria included inpatients still in intensive care (unstable condition) and forced discharged status.

The data were collected by purposive sampling, and 300 medical records were fulfilled inclusion and exclusion criteria. The collected data from the medical records (January to December 2018) were in the form of patients' identities such as gender, age, education, occupation, marital status, the use of antipsychotics, and orthostatic hypotension incidence. The data were analyzed using 
univariate analysis. The characteristics of patients, use of antipsychotics, and orthostatic hypotension incidence were presented in frequency and percentage tables.

\section{RESULTS AND DISCUSSION}

The population of inpatient schizophrenia was 1345 patients. Furthermore, the calculation of the number of samples (The Hosmer-Lemeshow test) obtained a minimum sample size of 298 patients. Based on the inclusion and exclusion criteria, 300 medical records were selected and analyzed. Demographic data from all selected patients were presented in Table I. The result showed that most patients were within the age group of $17-40$ years. Age was an important factor in the onset of schizophrenia since it most often occurred at the end of adolescence or adulthood. At the productive age (17-40 years), a person must be responsible for his life to survive economically and socially ${ }^{13}$. Some people could experience stress due to the burden of responsibility. This was triggered the emergence of stress conditions in a person ${ }^{14}$. The onset of schizophrenia in men is earlier than in women. The onset of schizophrenia in women is 3-5 years slower than in men. Women have two peaks of onset, in the age range of 25-30 years and $>45$ years, while men are peak for onset in the age range of 21-25 years $(<40 \text { years })^{15}$.

In Table I, it could be seen that $78.3 \%$ of schizophrenic patients were male, and $21.7 \%$ were female. The role of gonadal hormones such as estrogen can affect the risk of schizophrenia. Estrogen is known to provide neuroprotective effects so that pathologically women have a lower risk of developing schizophrenia than men ${ }^{16}$. Estrogen also has a neuroleptic effect through changes in postsynaptic dopaminergic signal transduction so that psychotic symptoms mediated by dopamine can be inhibited. This will indirectly affect the onset and course of schizophrenia in women. In addition to this explanation, the etiopathology of schizophrenia is also associated with stress factors. Estrogen can protect women from the adverse effects of social pressure ${ }^{17}$.

Most patients had education at primary and secondary levels (Elementary, junior, and high school). One of the studies assessed determinants of the onset of schizophrenia in outpatients at Prof. HB Saanin Mental Health Hospital, Padang, West Sumatra, obtained the results from the bivariate analysis that there was no significant difference between educational status on the onset of schizophrenia and non-schizophrenia ( $p>0.05)$. Therefore, educational status did not affect the onset of schizophrenia, but it depends on when the onset of schizophrenia occurred, which resulted in people with schizophrenia experiencing problems in continuing education ${ }^{18}$.

Based on employment status, it was known that most patients with schizophrenia did not work. Patients with early-onset cause cognitive dysfunction, so that it will adversely affect the education undertaken ${ }^{19}$. Patients with schizophrenia that experience schizophrenia for the first time at a young age generally result in these sufferers dropping out of school, making it difficult to find work and failing to build good relationships with others.

Table I. Patients' demographic data at Sambang Lihum Mental Health Hospital

\begin{tabular}{|c|c|c|c|}
\hline Characteristics & Categories & $\begin{array}{c}\text { Frequency } \\
\text { (n) }\end{array}$ & $\%$ \\
\hline \multirow[t]{3}{*}{ Age } & $\leq 40$ year & 224 & 74.7 \\
\hline & $>40$ year & 76 & 25.3 \\
\hline & Total & 300 & 100 \\
\hline \multirow[t]{3}{*}{ Sex } & Male & 235 & 78.3 \\
\hline & Female & 65 & 21.7 \\
\hline & Total & 300 & 100 \\
\hline \multirow[t]{4}{*}{ Education } & No education & 31 & 10.3 \\
\hline & $\begin{array}{l}\text { Elementary, junior, } \\
\text { and high school }\end{array}$ & 260 & 86.7 \\
\hline & University & 9 & 3.0 \\
\hline & Total & 300 & 100 \\
\hline \multirow[t]{3}{*}{ Occupation } & No occupation & 204 & 68.0 \\
\hline & Occupied & 96 & 32.0 \\
\hline & Total & 300 & 100 \\
\hline \multirow[t]{4}{*}{ Marital Status } & Single & 166 & 55.4 \\
\hline & Married & 61 & 20.3 \\
\hline & $\begin{array}{l}\text { Divorced- } \\
\text { widowed }\end{array}$ & 73 & 24.3 \\
\hline & Total & 300 & 100 \\
\hline
\end{tabular}


Schizophrenia also has adverse effects on the patient's life journey, including marital problems. Not a few in the end cause problems for patients in establishing relationships with partners, which impacts divorce ${ }^{20}$. This was also shown in Table $\mathbf{I}$, in which more patients were divorced/widowed than those who were still married.

Psychiatric drugs are ideally selective at specific receptors on specific nerve cells in the brain and do not affect other receptors or neurons. However, this ideal condition has not been found in antipsychotics. Several factors cause this non-ideal condition ${ }^{21}$. First, many molecules specifically bind to more than one receptor. For example, some antipsychotics bind to postsynaptic dopamine receptors and acetylcholine muscarinic receptors, resulting in side effects such as memory impairment, blurred vision, and constipation 22 .

The second problem is that those specific drug molecules can bind to dopamine receptors in the limbic system or basal ganglia. The effect produced when it binds to dopamine receptors in the limbic system will produce the desired antipsychotic effect. Meanwhile, if these molecules bind to dopamine receptors in the basal ganglia, and extrapyramidal side effects will appear in the form of tremors. Such drug molecules cannot be sent to just one part of the brain and absorbed there but instead distributed to different regions of the brain ${ }^{23}$. The third problem is that, among the receptor classes, many subtypes have been identified, and drug molecules usually not only interact with one subtype but can also bind with other subtypes. For example, it is known that there are approximately 14 subtypes of serotonin receptors, so drugs that work to increase brain serotonin levels will have many effects because some serotonin receptors are inhibitory and some are excitatory ${ }^{24}$.

Antipsychotics from either class can be used alone or with other psychotropic drugs, such as mood stabilizers or antidepressants. In some patients, especially those with schizophrenia, a combination of more than one antipsychotic drug may be needed to help control symptoms. However, this could pose additional risks for the patient, which must be taken into account ${ }^{25}$. Based on Table II, it was known that the most used treatment for schizophrenic patients was the combination (75.67\%), whereas the monotherapy was $11.3 \%$.

Table II. Number of antipsychotics used at Sambang Lihum Mental Health Hospital

\begin{tabular}{|c|c|c|}
\hline Drug's Name & $\begin{array}{l}\text { Frequency } \\
\text { (N) }\end{array}$ & $\%$ \\
\hline \multicolumn{3}{|l|}{ Monotherapy } \\
\hline Haloperidol & 46 & 15.33 \\
\hline Trifluoperazine & 1 & 0.33 \\
\hline Clozapine & 13 & 4.33 \\
\hline Olanzapine & 1 & 0.33 \\
\hline Risperidone & 12 & 4 \\
\hline Total & 73 & 24.33 \\
\hline \multicolumn{3}{|l|}{ Two antipsychotics } \\
\hline Chlorpromazine-trifluoperazine & 1 & 0.33 \\
\hline Haloperidol-chlorpromazine & 11 & 3.67 \\
\hline Haloperidol-haloperidol (IV) & 7 & 2.33 \\
\hline Clozapine-risperidone & 6 & 2 \\
\hline Chlorpromazine-risperidone & 3 & 1 \\
\hline Haloperidol-clozapine & 93 & 31 \\
\hline Haloperidol-olanzapine & 2 & 0.67 \\
\hline Haloperidol-risperidone & 22 & 7.33 \\
\hline Trifluoperazine-clozapine & 9 & 3 \\
\hline Trifluoperazine-olanzapine & 1 & 0.33 \\
\hline Trifluoperazine-risperidone & 18 & 6 \\
\hline Total & 174 & 57.7 \\
\hline \multicolumn{3}{|l|}{ Three antipsychotics } \\
\hline $\begin{array}{l}\text { Chlorpromazine-haloperidol- } \\
\text { haloperidol (IV) }\end{array}$ & 3 & 1 \\
\hline $\begin{array}{l}\text { Chlorpromazine-haloperidol- } \\
\text { trifluoperazine }\end{array}$ & 3 & 1 \\
\hline $\begin{array}{l}\text { Chlorpromazine-haloperidol- } \\
\text { risperidone }\end{array}$ & 4 & 1.33 \\
\hline $\begin{array}{l}\text { Haloperidol (IV)-trifluoperazine- } \\
\text { chlorpromazine }\end{array}$ & 1 & 0.33 \\
\hline Chlorpromazine-haloperidol-clozapine & 7 & 2.33 \\
\hline $\begin{array}{l}\text { Chlorpromazine-trifluoperazine- } \\
\text { clozapine }\end{array}$ & 1 & 0.33 \\
\hline $\begin{array}{l}\text { Chlorpromazine-trifluoperazine- } \\
\text { olanzapine }\end{array}$ & 1 & 0.33 \\
\hline $\begin{array}{l}\text { Chlorpromazine-trifluoperazine- } \\
\text { risperidone }\end{array}$ & 2 & 0.67 \\
\hline Haloperidol-haloperidol (IV)-clozapine & 5 & 1.67 \\
\hline $\begin{array}{l}\text { Trifluoperazine-haloperidol- } \\
\text { risperidone }\end{array}$ & 4 & 1.33 \\
\hline Trifluoperazine-haloperidol-clozapine & 5 & 1.67 \\
\hline trifluoperazine-haloperidol-olanzapine & 1 & 0.33 \\
\hline Clozapine-risperidone-chlorpromazine & 1 & 0.33 \\
\hline Clozapine-risperidone-trifluoperazine & 4 & 1.33 \\
\hline Risperidone-clozapine-haloperidol & 10 & 3.33 \\
\hline Total & 52 & 17.33 \\
\hline \multicolumn{3}{|l|}{ Four antipsychotics } \\
\hline $\begin{array}{l}\text { Trifluoperazine-haloperidol-clozapine- } \\
\text { risperidone }\end{array}$ & 1 & 0.33 \\
\hline $\begin{array}{l}\text { Haloperidol-risperidone-clozapine- } \\
\text { olanzapine }\end{array}$ & 1 & 0.33 \\
\hline Total & 2 & 0.66 \\
\hline
\end{tabular}


Most psychopharmaceutical drugs play a role in the neurotransmitters, including serotonin, norepinephrine, dopamine, acetylcholine, glutamate, and GABA. These six neurotransmitters are the central target systems for psychotropic drugs ${ }^{26}$. It is known that the brain has natural neurotransmitters; for example, the brain makes its morphine, known as $\beta$-endorphin. The brain also makes its antidepressants, its anxiolytics, and even its hallucinogens. Therefore, drugs often mimic the brain's natural neurotransmitters ${ }^{27}$. Initially, it was thought that each neuron uses only one neurotransmitter to transmit information and uses the same neurotransmitter across all its synapses. However, it is known that many neurons use more than one neurotransmitter at a single synapse. Besides, the input to each neuron at various locations also involves many neurotransmitters. This is the basis for combining drugs to simultaneously modify several neurotransmitters in mental disorders, such as schizophrenia ${ }^{28}$.

The range of antipsychotic drugs available is very wide, and their effectiveness can also vary from individual to individual. Besides, not all patients respond fully to one antipsychotic, and in this situation, a combination of antipsychotics is often prescribed. Evidence for the benefit of using one or more antipsychotics in combination is often unclear. Based on a systematic review, it was found that the use of combination therapy in schizophrenic patients was no better than monotherapy for the patient's clinical response (RR 0.73 CI $0.64-0.83)^{29}$.

In Figure 1, it could be seen that the use of typical antipsychotics by monotherapy was more than the use of atypical ones. The use of two antipsychotics could also be seen as the combination of typical and atypical antipsychotics at most of the other combinations (two antipsychotics). Meanwhile, the combination of three antipsychotics shows that the combination of two typical and one atypical has a more significant percentage than the other combinations (three antipsychotics).

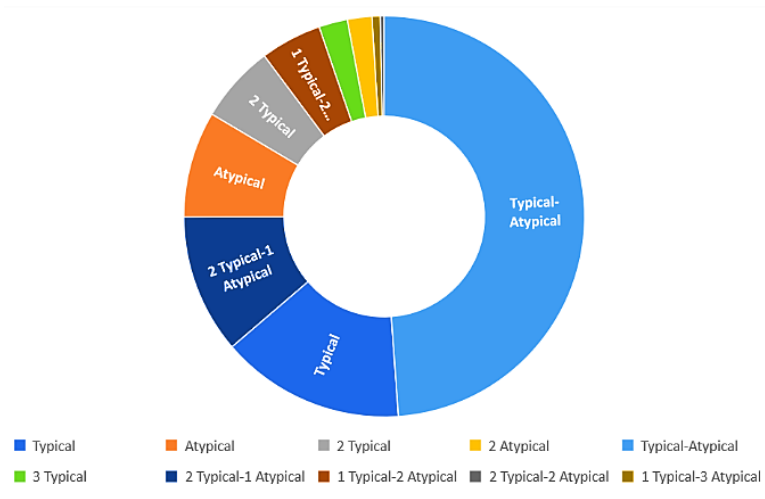

Figure 1. Typical and atypical antipsychotics used at Sambang Lihum Mental Health Hospital

Typical antipsychotics is another name for the firstgeneration antipsychotics (FGA), which has a mechanism of action mainly through inhibition of dopamine type 2 (D2) receptors located in the central nervous system (mesolimbic areas). Besides D2 antagonism, first-generation antipsychotics affect other receptors, such as muscarinic, adrenergic a1, and histamine-1. Meanwhile, second-generation antipsychotics (SGA), also called atypical antipsychotics, work by antagonizing the D2 receptor and the 5-HT2A serotonin receptor in the central nervous system. Atypical antipsychotics have lower affinity and occupancy for dopaminergic receptors. They have a higher affinity for 5-HT2A receptors than D2 receptors ${ }^{22}$. There are important differences in side effect profiles between typical and atypical. Typical antipsychotics have a higher risk of neurological side effects than atypical antipsychotics. The neurological side effects include tardive dyskinesia, extrapyramidal symptoms, dystonia, and others, while atypical antipsychotics have an increased risk of metabolic disorders such as hyperglycemia, obesity, and dyslipidemia 6 .

Figure 2 showed that the incidence of orthostatic hypotension occurred in respondents was 32.67\% (N=98). Antipsychotic drugs often cause side effects, 
ranging from mild to severe. Each antipsychotic drug has different side effects from one another. Some of the side effects of administering antipsychotics include metabolic disorders, movement disorders, increased sedation, sexual dysfunction, postural or orthostatic hypotension, cardiac arrhythmias, and death. The use of antipsychotics is one of the causes of orthostatic hypotension ${ }^{6}$.

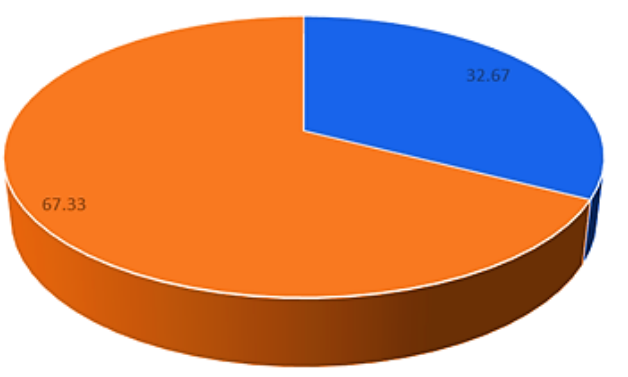

Figure 2. Percentage of orthostatic hypotension at Sambang Lihum Mental Health Hospital

Table III shows that patients who were given typical antipsychotics such as haloperidol, trifluoperazine, clozapine, and olanzapine experienced side effects of orthostatic hypotension. Meanwhile, patients who were given risperidone did not find any incidence of orthostatic hypotension. In the combination of two antipsychotics, chlorpromazine-trifluoperazine and chlorpromazine-risperidone, there were no side effects of orthostatic hypotension, whereas, in other combinations, orthostatic hypotension was found. The combination of three antipsychotics, chlorpromazine-haloperidolrisperidone, trifluoperazine-haloperidol-olanzapine, and clozapine-risperidone-chlorpromazine did not occur orthostatic hypotension, whereas, in other combinations, there were side effects of orthostatic hypotension. Furthermore, the combination of four antipsychotics did not occur side effects of orthostatic hypotension. Based on Table III, it could be seen that patients who were given either haloperidol or clozapine monotherapy or in combination experienced orthostatic hypotension. The side effects of orthostatic hypotension occurred both in the typical and atypical antipsychotics groups.
Table II. Incidence of orthostatic hypotension at Sambang Lihum Mental Health Hospital

\begin{tabular}{|c|c|c|c|}
\hline Antipsychotics & $\begin{array}{l}\text { Number } \\
\text { of } \\
\text { patients }\end{array}$ & $\begin{array}{l}\text { Orthostatic } \\
\text { hypotension } \\
\text { frequency }\end{array}$ & $\%$ \\
\hline \multicolumn{4}{|l|}{ Monotherapy } \\
\hline Haloperidol & 46 & 25 & 54.35 \\
\hline Trifluoperazine & 1 & 1 & 100 \\
\hline Clozapine & 13 & 11 & 84.62 \\
\hline Olanzapine & 1 & 1 & 100 \\
\hline Risperidone & 12 & 0 & 0 \\
\hline \multicolumn{4}{|l|}{ Two antipsychotics } \\
\hline $\begin{array}{l}\text { Chlorpromazine- } \\
\text { Trifluoperazine }\end{array}$ & 1 & 0 & 0 \\
\hline $\begin{array}{l}\text { Chlorpromazine- } \\
\text { Risperidone }\end{array}$ & 3 & 0 & 0 \\
\hline $\begin{array}{l}\text { Haloperidol- } \\
\text { Chlorpromazine }\end{array}$ & 11 & 3 & 27.27 \\
\hline Haloperidol-Haloperidol & 7 & 3 & 42.86 \\
\hline Clozapine-Risperidone & 6 & 1 & 16.67 \\
\hline Haloperidol-Clozapine & 93 & 14 & 15.05 \\
\hline Haloperidol-Olanzapine & 2 & 1 & 50 \\
\hline Haloperidol-Risperidone & 22 & 7 & 31.82 \\
\hline Trifluoperazine-Clozapine & 9 & 2 & 22.22 \\
\hline $\begin{array}{l}\text { Trifluoperazine- } \\
\text { Olanzapine }\end{array}$ & 1 & 1 & 100 \\
\hline $\begin{array}{l}\text { Trifluoperazine- } \\
\text { Risperidone }\end{array}$ & 18 & 1 & 5.56 \\
\hline \multicolumn{4}{|l|}{ Three antipsychotics } \\
\hline $\begin{array}{l}\text { Chlorpromazine- } \\
\text { Haloperidol-Haloperidol }\end{array}$ & 3 & 1 & 33.33 \\
\hline $\begin{array}{l}\text { Chlorpromazine- } \\
\text { Haloperidol- } \\
\text { Trifluoperazine }\end{array}$ & 3 & 3 & 100 \\
\hline $\begin{array}{l}\text { Chlorpromazine- } \\
\text { Haloperidol-Risperidone }\end{array}$ & 4 & 0 & 0 \\
\hline $\begin{array}{l}\text { Haloperidol- } \\
\text { Trifluoperazine- } \\
\text { Chlorpromazine }\end{array}$ & 1 & 1 & 100 \\
\hline $\begin{array}{l}\text { Chlorpromazine- } \\
\text { Haloperidol-Clozapine }\end{array}$ & 7 & 3 & 42.86 \\
\hline $\begin{array}{l}\text { Chlorpromazine- } \\
\text { Trifluoperazine-Clozapine }\end{array}$ & 1 & 1 & 100 \\
\hline $\begin{array}{l}\text { Chlorpromazine- } \\
\text { Trifluoperazine- } \\
\text { Olanzapine }\end{array}$ & 1 & 1 & 100 \\
\hline $\begin{array}{l}\text { Chlorpromazine- } \\
\text { Trifluoperazine- } \\
\text { Risperidone }\end{array}$ & 2 & 1 & 50 \\
\hline $\begin{array}{l}\text { Trifluoperazine- } \\
\text { Haloperidol-Risperidone }\end{array}$ & 4 & 4 & 100 \\
\hline $\begin{array}{l}\text { Trifluoperazine- } \\
\text { Haloperidol-Clozapine }\end{array}$ & 5 & 2 & 40 \\
\hline $\begin{array}{l}\text { Trifluoperazine- } \\
\text { Haloperidol-Olanzapine }\end{array}$ & 1 & 0 & 0 \\
\hline $\begin{array}{l}\text { Haloperidol-Haloperidol- } \\
\text { Clozapine }\end{array}$ & 5 & 4 & 80 \\
\hline $\begin{array}{l}\text { Clozapine-Risperidone- } \\
\text { Trifluoperazine }\end{array}$ & 4 & 4 & 100 \\
\hline $\begin{array}{l}\text { Clozapine-Risperidone- } \\
\text { Chlorpromazine }\end{array}$ & 1 & 0 & 0 \\
\hline $\begin{array}{l}\text { Risperidone-Clozapine- } \\
\text { Haloperidol }\end{array}$ & 10 & 2 & 20 \\
\hline \multicolumn{4}{|l|}{ Four antipsychotics } \\
\hline $\begin{array}{l}\text { Trifluoperazine- } \\
\text { Haloperidol-Clozapine- } \\
\text { Risperidone }\end{array}$ & 1 & 0 & 0 \\
\hline $\begin{array}{l}\text { Haloperidol-Risperidone- } \\
\text { Clozapine-Olanzapine }\end{array}$ & 1 & 0 & 0 \\
\hline Total & 300 & 98 & 32.67 \\
\hline
\end{tabular}


Most antipsychotics are dopamine D2 receptor antagonists, and an antipsychotic effect is mediated by mesolimbic D2 dopaminergic receptor blockade mechanisms ${ }^{22}$. However, some other antipsychotics also affect other receptors such as serotonin 5-HT2 receptors, muscarinic receptors (M2), and a-adrenoceptors, especially a1-adrenoceptors 9 . Based on in vivo and in vitro studies conducted on Wistar strain rats, it was concluded that a1-adrenoceptor plays a significant role in the mechanism of the effect of orthostatic hypotension. However, it has not been able to explain whether the same thing happens in humans, so further research is needed ${ }^{30}$.

Antipsychotics of the typical and atypical classes tend to cause orthostatic hypotension, which is highly dependent on the degree of a1-adrenoceptor antagonism. This was especially the case in the low potency typical antipsychotic group and atypical, i.e., clozapine. Clozapine was reported as atypical antipsychotics that are most commonly associated with orthostatic hypotension. In addition, this can also occur with risperidone and quetiapine, especially with fast titrations. Side effects of orthostatic hypotension are reported to be more frequent in some patient conditions, such as elderly patients at risk of falls, patients with cardiovascular disease, and patients receiving antihypertensive therapy. Therefore, it is necessary to manage the dosage carefully to tolerate the side effects. In addition, it is advisable to make appropriate treatment options, including reducing or splitting the dose or switching to drugs with lower antiadrenergic effects ${ }^{5}$.

The clinical study "CATIE" (Clinical Antipsychotic Trials of Intervention Effectiveness) aims to compare the effectiveness and tolerability of atypical antipsychotics with typical antipsychotics. The results showed that two atypical antipsychotics had the highest orthostatic hypotension side effects compared to other antipsychotics: clozapine by $24 \%$ and quetiapine by $27 \%$. This is because both have a high affinity for a1adrenoceptor $^{31}$. Some atypical antipsychotics that also have the potential to cause orthostatic hypotension include aripiprazole, olanzapine, paliperidone, asenapine, iloperidone, risperidone, and ziprasidone. This is strongly suspected to be caused by inhibition of the a1-adrenoceptor and the anticholinergic effect of these antipsychotic drugs. Stimulation of a1adrenoceptors causes vascular vasoconstriction, so when these receptors are inhibited, it causes vasodilation. Vasodilation resulting in a decrease in blood pressure ${ }^{32}$.

\section{CONCLUSION}

The incidence of orthostatic hypotension side effects in patients with schizophrenia at Sambang Lihum Mental Hospital, South Kalimantan, Indonesia was 32.67\% (98 patients).

\section{ACKNOWLEDGMENT}

This research was funded by the 2020 PNBP of Universitas Lambung Mangkurat. The author would like to thank the Sambang Lihum Mental Health Hospital for the permission given for this research.

\section{AUTHORS' CONTRIBUTION}

Noor Cahaya: designed and coordinated study, led on data analysis, wrote first and final drafts. Sandra Putri Wijaya: data collection. Khoerul Anwar: coordinate data collection and data interpretation. all authors have read and approved the final manuscript.

\section{DATA AVAILABILITY}

None. 


\section{CONFLICT OF INTEREST}

The authors declare no conflict of interest.

\section{REFERENCES}

1. Loch AA. Schizophrenia, Not a Psychotic Disorder: Bleuler Revisited. Front Psychiatry. 2019;10:328. doi:10.3389/fpsyt.2019.00328

2. Charlson FJ, Ferrari AJ, Santomauro DF, Diminic S, Stockings E, Scott JG, et al. Global Epidemiology and Burden of Schizophrenia: Findings from the Global Burden of Disease Study 2016. Schizophr Bull. 2018;44(6):1195-203. doi:10.1093/schbul/sby058

3. Ministry of Health Republic of Indonesia. Hasil Utama Riskesdas 2018. Jakarta: Health Research and Development Agency, Ministry of Health Republic of Indonesia; 2018.

4. Rahman T, Lauriello J. Schizophrenia: An Overview. Focus (Am Psychiatr Publ). 2016;14(3):300-7. doi:10.1176/appi.focus.20160006

5. StępnickiP, KondejM, Kaczor AA. Current Concepts and Treatments of Schizophrenia. Molecules. 2018;23(8):2087. doi:10.3390/molecules23082087

6. Stroup TS, Gray N. Management of common adverse effects of antipsychotic medications. World Psychiatry. 2018;17(3):341-56. doi:10.1002/wps.20567

7. Ferinauli F, Narulita S, Hijriyati Y. Effect of antipsychotic drugs and orthostatic hypotension on the risk of falling in schizophrenic patients. J Public Health Res. 2021;19(2):2184. doi:10.4081/jphr.2021.2184

8. Arnold AC, Shibao C. Current Concepts in Orthostatic Hypotension Management. Curr Hypertens Rep. 2013;15(4):304-12. doi:10.1007/s11906-013-0362-3

9. Siafis S, Tzachanis D, Samara M, Papazisis G. Antipsychotic Drugs: From Receptor-binding Profiles to Metabolic Side Effects. Curr Neuropharmacol. 2018;16(8):1210-23. doi:10.2174/1570159X15666170630163616

10. Rivasi G, Rafanelli M, Mossello E, Brignole M, Ungar A. Drug-Related Orthostatic Hypotension: Beyond Anti-Hypertensive Medications. Drugs Aging. 2020;37(10):725-38. doi:10.1007/s40266-020-00796-5
11. Mauri MC, Paletta S, Maffini M, Colasanti A, Dragogna F, Di Pace C, et al. Clinical pharmacology of atypical antipsychotics: an update. EXCLI J. 2014;13:1163-91.

12. Yulianty MD, Cahaya N, Srikartika VM. Studi Penggunaan Antipsikotik dan Efek Samping pada Pasien Skizofrenia di Rumah Sakit Jiwa Sambang Lihum Kalimantan Selatan. JSFK (Jurnal Sains Farmasi \& Klinis). 2017;3(2):153-64. doi:10.29208/jsfk.2017.3.2.108

13. Patton GC, Sawyer SM, Santelli JS, Ross DA, Afifi R, Allen NB, et al. Our future: a Lancet commission on adolescent health and wellbeing. Lancet. 2016;387(10036):2423-78. doi:10.1016/S01406736(16)00579-1

14. Williams DR. Stress and the Mental Health of Populations of Color: Advancing Our Understanding of Race-related Stressors. J Health Soc Behav. 2018;59(4):466-85. doi:10.1177/0022146518814251

15. Li R, Ma X, Wang G, Yang J, Wang C. Why sex differences in schizophrenia? J Transl Neurosci. 2016;1(1):37-42

16. Ran MS, Mao WJ, Chan CLW, Chen EYH, Conwell Y. Gender differences in outcomes in people with schizophrenia in rural China: 14-year follow-up study. $\quad \mathrm{Br} \quad \mathrm{J}$ Psychiatry. 2015;206(4):283-8. doi:10.1192/bjp.bp.113.139733

17. Gogos A, Sbisa AM, Sun J, Gibbons A, Udawela M, Dean B. A Role for Estrogen in Schizophrenia: Clinical and Preclinical Findings. Int J Endocrinol. 2015;2015:615356. doi:10.1155/2015/615356

18. Soewadi E, Pramono D. Determinan terhadap Timbulnya Skizofrenia pada Pasien Rawat Jalan di Rumah Sakit Jiwa Prof. Hb Saanin Padang Sumatera Barat. Berita Kedokteran Masyarakat. 2010;26(2):7180. doi:10.22146/bkm.3471

19. Teigset CM, Mohn C, Brunborg C, Juuhl-Langseth M, Holmén A, Rund BR. Do clinical characteristics predict the cognitive course in early-onset schizophrenia-spectrum disorders? J Child Psychol Psychiatry. 2018;59(9):1012-23. doi:10.1111/jcpp.12896

20. Golics CJ, Basra MKA, Finlay AY, SalekS. The impact of disease on family members: a critical aspect of medical care. J R Soc Med. 2013;106(10):399-407. doi:10.1177/0141076812472616 
21. Miller R. Mechanisms of Action of Antipsychotic Drugs of Different Classes, Refractoriness to Therapeutic Effects of Classical Neuroleptics, and Individual Variation in Sensitivity to their Actions: PART I. Curr Neuropharmacol. 2009;7(4):302-14. doi:10.2174/157015909790031229

22. Li P, Snyder GL, Vanover KE. Dopamine Targeting Drugs for the Treatment of Schizophrenia: Past, Present and Future. Curr Top Med Chem. 2016;16(29):3385-403. doi:10.2174/1568026616666160608084834

23. McCutcheon RA, Abi-Dargham A, Howes OD. Schizophrenia, Dopamine and the Striatum: From Biology to Symptoms. Trends Neurosci. 2019;42(3):205-20. doi:10.1016/j.tins.2018.12.004

24. De Ponti F. Pharmacology of serotonin: what a clinician should know. Gut. 2004;53(10):1520-35. doi:10.1136/gut.2003.035568

25. Correll CU, Defraux J, De Lepeleire J, De Hert M. Effects of antipsychotics, antidepressants and mood stabilizers on risk for physical diseases in people with schizophrenia, depression and bipolar disorder. World Psychiatry. 2015;14(2):119-36. doi:10.1002/wps.20204

26. Iversen L. Neurotransmitter transporters and their impact on the development of psychopharmacology. $\mathrm{Br} \quad \mathrm{J}$ Pharmacol. 2006;147(Suppl 1):S82-8. doi:10.1038/sj.bjp.0706428

27. Sprouse-Blum AS, Smith G, Sugai D, Parsa FD. Understanding Endorphins and Their Importance in Pain Management. Hawaii Med J. 2010;69(3):70-1

28. Svensson E, Apergis-Schoute J, Burnstock G, Nusbaum MP, Parker D, Schiöth HB. General Principles of Neuronal Co-transmission: Insights from Multiple Model Systems. Front Neural Circuits. 2019;12:117. doi:10.3389/fncir.2018.00117

29. Ortiz-Orendain J, Castiello-de Obeso S, ColungaLozano LE, Hu Y, Maayan N, Adams CE. Antipsychotic combinations for schizophrenia. Cochrane Database Syst Rev. 2017;6(6):CD009005. doi:10.1002/14651858.cd009005.pub2

30. Nourian Z, Mow T, Muftic D, Burek S, Pedersen ML, Matz J, et al. Orthostatic hypotensive effect of antipsychotic drugs in Wistar rats by in vivo and in vitro studies of alpha1-adrenoceptor function. Psychopharmacology. 2008;199(1):15-27.
31. Sakurai H, Bies RR, Stroup ST, Keefe RSE, Rajji TK, Suzuki T, et al. Dopamine D2 receptor occupancy and cognition in schizophrenia: analysis of the CATIE data. Schizophr Bull. 2013;39(3):564-74. doi:10.1093/schbul/sbr189

32. Khasawneh FT, Shankar GS. Minimizing cardiovascular adverse effects of atypical antipsychotic drugs in patients with schizophrenia. Cardiol Res Pract. 2014;2014:273060. doi:10.1155/2014/273060 doi:10.1007/s00213-007-1064-9 